\title{
Association between Epstein-Barr Virus Infection and Gastric Cancer: A Systematic Review and Meta- analysis
}

\section{Ahmad Tavakoli}

Iran University of Medical Sciences https://orcid.org/0000-0003-1857-0610

\section{Seyed Hamidreza Monavari}

Iran University of Medical Sciences

\section{Farid Solaymani Mohammadi}

University of North Dakota

Seyed Jalal Kiani

Iran University of Medical Sciences

\section{Saber Armat}

Shiraz University

Mohammad Farahmand ( $\triangle$ m_farahmand@razi.tums.ac.ir)

https://orcid.org/0000-0002-9648-9298

\section{Research article}

Keywords: Epstein-Barr virus; EBV; Gastric Cancer; Stomach Cancer; Gastric Carcinoma; Meta-Analysis

Posted Date: March 30th, 2020

DOI: https://doi.org/10.21203/rs.2.24262/v2

License: (9) (i) This work is licensed under a Creative Commons Attribution 4.0 International License. Read Full License

Version of Record: A version of this preprint was published at BMC Cancer on June 1st, 2020. See the published version at https://doi.org/10.1186/s12885-020-07013-x. 


\section{Abstract}

Background: Numerous studies conducted over the past 30 years have pointed to the presence of Epstein-Barr virus (EBV) in gastric cancer samples. This study was aimed to provide a meta-analytic review of the prevalence of EBV in gastric cancer patients, and to clarify the relationship between EBV infection and gastric cancer. Methods: A literature search was performed electronically using online databases for English language publications until July 1, 2019. The pooled EBV prevalence and 95\% confidence intervals (Cls) were estimated using a random-effects model. To determine the association between EBV and gastric cancer, pooled odds ratio (OR) and its $95 \% \mathrm{Cl}$ were computed for case-control studies with matched pairs design. Results: The pooled prevalence of EBV in 20411 gastric cancer patients was $8.78 \%$ (95\% Cl: 7.75-9.93\%; I $2=83.0 \%$ ). The proportion of EBV-associated gastric cancer among male cases was significantly higher than among female cases $(10.85 \%$, vs. $5.72 \%)(P<0.01)$. EBV was more prevalent in the cardia (12.47\%) and the body $(11.68 \%)$ compared to the antrum $(6.29 \%)$ ( $\mathrm{P}<0.01)$. There were 20 studies with matched pairs design, including tumor and tumor-adjacent normal tissue pairs from 4116 gastric cancer patients. The pooled OR between EBV infection and gastric cancer risk was 18.56 (95\% Cl: 15.68-21.97; I 2 = 55.4\%). Conclusions: EBV infection is associated with more than 18 times increase the risk of gastric cancer. Although the prevalence of EBV was higher in male patients than in female patients with gastric cancer, women are more likely than men to develop EBVassociated gastric cancer.

\section{Background}

According to GLOBOCAN statistics in 2018, gastric cancer is the fifth most frequently diagnosed cancer and the third leading cause of cancer-related mortality in the world accounted for $8.2 \%$ of all cancer deaths. Over 1,000,000 new cases of gastric cancer diagnosed in 2018 around the world, with an estimated 783,000 deaths [1]. Gastric cancer arises from a combination of multiple environmental and genetic risk factors, and infectious agents are one of the critical environmental factors which contribute to an increased risk of developing several malignancies [2].

Epstein-Barr virus (EBV), as a member of the Herpesviridae family, is the first described human cancer virus and is responsible for approximately $1.8 \%$ of all human cancers, including Hodgkin lymphoma, Burkitt lymphoma, NK/T cell lymphoma, and nasopharyngeal carcinoma [3]. However, the role of EBV in the development of other malignancies is still under investigation. At the beginning of the 1990s, the association between EBV and gastric carcinomas was found. The first report was made by Burke et al. in a case of lymphoepithelial-like gastric carcinoma [4], and afterwards, the association was observed in gastric adenocarcinoma [5]. Subsequently, numerous studies demonstrated an essential role of EBV in gastric carcinogenesis.

To date, the mechanisms of EBV-associated gastric cancer are still not comprehensively clarified. Generally, virologic aspects, in conjunction with host genome abnormalities, co-potentiate the cancer progression. Regarding the virologic background, the EBV genome encodes oncoproteins, which target 
important cellular pathways. EBV-associated gastric cancer belongs to latency type I infection, in which only EBNA1, EBER, BamHI A rightward transcript (BART), and BART miRNAs are highly expressed, while the latent membrane protein 2A (LMP2A) can be detected in $40 \%$ of cases [6]. Evidence suggests that latent infection by EBV and the expression of the EBV latent genes lead to the host genome abnormalities like aberrant DNA methylation, which has attracted more attention in recent years [7].

The gold standard for the diagnosis of EBV infection in histopathologic samples is ISH, which detects EBV-encoded small RNA-1 (EBER1). EBER1 is highly expressed in latently EBV-infected cells (up to $10^{7}$ copies per cell) [8]. EBER1 signals are commonly identified in the nuclei of nearly all carcinoma cells in EBV-associated gastric carcinoma [9]. PCR-based methods are also widely used for the diagnosis of EBV infection. Although PCR is a cost-efficient and simple technique for the detection of EBV infection, it is prone to false-positive results due to its low specificity. The low specificity of PCR can be explained by the fact that memory cells and/or non-tumor, bystander lymphocytes may also be investigated for the presence of the EBV genome. Therefore, PCR-based methods are more sensitive but less specific than the gold standard ISH method to detect EBV $[10,11]$.

There are several published meta-analyses addressing the prevalence of EBV among gastric cancer patients [12-16]; however, their results are out of date and only descriptive. On the other hand, they did not perform any analysis to estimate the association between the EBV and gastric cancer risk. The last metaanalysis conducted by Bae et al. focused on the results of case-control studies published up to 2014 to prove the relationship between EBV and gastric cancer for the first time [17]. However, some important variables such as gender, type of samples, and tumor anatomical location did not include in their metaanalysis. Our meta-analysis aims to determine the association of EBV infection with gastric cancer and to provide an updated pooled prevalence of EBV infection among gastric cancer patients. It is anticipated that the results of the present study will direct future experimental studies toward elucidating the role of EBV infection in the carcinogenesis of gastric cancer, and will inform clinicians and policy-makers to improve preventive intervention and control.

\section{Methods}

The present systematic review and meta-analysis was performed according to the recommendations of the Preferred Reporting Items for Systematic Reviews and Meta-Analyses (PRISMA) statement [18].

\section{Search strategy}

A rigorous literature search was conducted using PubMed, Web of Science, Scopus, EMBASE, and Google scholar to identify all published articles reporting the prevalence of EBV in patients with gastric cancer. Databases were searched from inception to July 1, 2019. The bibliographies of all articles obtained were also reviewed for additional relevant publications. The list of keywords used for this systematic review and meta-analysis is provided in Appendix 1.

\section{Study selection}


All records were imported to EndNote software version X8 (Thomson Reuters, California, USA), and duplicate entries were removed. The screening of the title and abstract of the remaining records was independently conducted by two researchers. The full-texts of the remaining records were then retrieved and reviewed, and any disagreements were resolved through discussion by a third investigator.

\section{Eligibility criteria}

Studies were considered eligible for inclusion in the present meta-analysis, if they met the following criteria: (1) Studies using cross-sectional and case-control designs reporting the prevalence of EBV infection in patients with different types of gastric carcinoma; (2) Studies using EBER-ISH technique to detect the presence of EBV transcripts or nucleic acids; (3) Studies using the formalin-fixed paraffinembedded (FFPE) tissues and biopsies samples; (4) Studies published in peer-reviewed journals in the English language.

Studies with following characteristics were excluded from the present meta-analysis: (1) Studies using serological techniques such as enzyme-linked immunosorbent assay (ELISA) to detect circulating antibodies to EBV infection; (2) Studies evaluating the presence of EBV in serum, plasma or peripheral blood mononuclear cell (PBMC) samples; (3) Studies assessing the presence of EBV in gastric carcinoma patients with underlying disorders; (4) Studies evaluating the presence of EBV by molecular methods such as PCR, nested-PCR and Real-Time PCR; (5) Studies addressing remnant gastric cancer, gastric lymphoma, and other types of gastric malignancies; (6) Studies using techniques other than EBER-ISH, (7) Studies published in languages other than English; (8) Reviews, letters to the editor, abstracts, and case reports.

\section{Data extraction}

Two investigators independently extracted data from all eligible studies in a pre-designed data extraction form using Microsoft Excel 2013 (Microsoft Corporation, Redmond, Washington, USA). The two investigators cross-checked each other's data extraction, and any disagreements were resolved by a third investigator. The following characters were extracted from each study: first author's name, publication date, study location, study design, sample size, sex, type of specimen, histological type, number of EBVpositive samples, tumor anatomical location, depth of invasion, tumor stage, and lymph node invasion.

\section{Statistical analysis}

The present meta-analysis had two primary purposes; first, providing an updated estimate of the pooled prevalence of EBV among patients with gastric cancer, and secondly, investigating the association between EBV and the development of gastric cancer. A random-effect meta-analysis using the inverse variance method was applied to estimate the pooled prevalence of EBV (DerSimonian-Laird method) [19]. The logit transformation was used for stabilizing the variance and data normalization, and the ClopperPearson method was applied to determine the $95 \%$ confidence intervals (Cls) for proportions [20]. 
To evaluate the strength of the association between EBV infection and gastric cancer risk, the pooled odds ratios (ORs) with $95 \%$ Cls were generated from a random-effects model based on the DerSimonianLaird method. For studies with a zero cell, a continuity correction of 0.5 was applied. We also conducted subgroup analyses to identify the possible sources of heterogeneity. The heterogeneity among the studies was assessed through $\mathrm{I}^{2}$ statistics [21]. To explore potential publication bias and symmetric assumption among the included studies, a Begg's funnel plot was constructed [22]. All the abovementioned analyses were conducted using the R package "meta" (version 3.5.3 [2019-03-11]) [23, 24], and $P$ values less than 0.05 were considered statistically significant. Furthermore, for each case-control study with matched pairs design, we separately computed matched-pairs OR and its corresponding variance using the "escalc" function in the R "metafor" package [25] (version 2.1-0 [2019-05-13]. The obtained results were then used for performing meta-analysis to calculate the matched pairs pooled OR.

\section{Results}

\section{Literature selection}

The electronic database searches were identified 597 articles, and additional 14 relevant records were found through bibliographic hand searching. Of these 611 articles, 151 duplicates were excluded, so a total of 460 articles was screened according to their title and abstract. A total of 353 articles was eliminated after reading the title and abstract due to apparent irrelevance. The remaining 107 articles were assessed for agreement with the inclusion and exclusion criteria by the full-text review, and finally, 72 papers were included in this systematic review and meta-analysis. Figure 1 shows the process of literature retrieval and screening using a flow chart.

\section{Study characteristics}

Table 1 shows the characteristics of eligible studies included in the systematic review and meta-analysis. Out of 72 studies, 30 were case-control, and 42 were cross-sectional in design. Publication dates ranged from 1993-2019, and over half of the studies (59.7\%) described specimens recruited before 2005. Among the studies included in this meta-analysis, four were from Africa, 16 were from America, 36 were from Asia, and 17 were from Europe. Of the 73 studies included, 47 provided information on patients' sex, 41 studies provided data on histological type, and 35 had data on tumor anatomical location. The most extensive study included 2226 gastric cancer cases, and the smallest covered 19 cases. Most studies were from Japan $(n=15)$.

\section{The prevalence of EBV among gastric cancer patients}

The first aim of the current study was to determine the pooled prevalence of EBV in 20411 gastric cancer patients from 27 countries, and the range was from $1.69 \%$ to $43.75 \%$ of the selected individual studies. The pooled prevalence of EBV among gastric cancer patients was $8.78 \%$ (95\% Cl: $7.75-9.93 \% ; I^{2}=83.0 \%$ ). The highest and lowest prevalence of EBV were found in gastric cancer patients from Poland and the United Kingdom, respectively (25.57\%, 95\%Cl: $6.13-64.36 \%$ vs. $2.78 \%, 95 \% \mathrm{Cl}: 1.51-5.06 \%)$. Table 2 
presents more detailed information on the prevalence of EBV infection in gastric cancer patients for subgroups.

\section{The association between EBV and gastric cancer}

Among 30 case-control studies, 20 had matched pairs design, including tumor and tumor-adjacent normal tissue pairs from 4116 gastric cancer patients. The remaining ten non-matched case-control studies included 911 cases of gastric cancer and 436 controls. Using data obtained from studies with non-matched pairs design, the pooled OR of EBV infection was 3.31 (95\% Cl: $0.95-11.54 ; \mathrm{I}^{2}=55.0 \%$ ), whereas the pooled OR for studies with matched pairs design was $18.56\left(95 \% \mathrm{Cl}: 15.68-21.97 ; \mathrm{I}^{2}=\right.$ $55.4 \%)$, indicating a solid significant positive relationship between EBV infection and gastric cancer (Figure 2). So, we further performed a subgroup analysis for studies with matched pairs design. Table 3 presents details on the association between EBV infection and gastric cancer risk for subgroups. Finally, the analysis of the funnel plot did not show evidence of asymmetry (Figure 3), and Begg's test indicated an absence of publication bias among all the studies included in this meta-analysis $(P=0.18)$.

\section{Discussion}

Our meta-analysis showed that the pooled prevalence of EBV among gastric cancer patients from 27 countries is $8.78 \%\left(95 \% \mathrm{Cl}: 7.75-9.93 \% ; \mathrm{I}^{2}=83.0 \%\right)$. We chose strict inclusion and exclusion criteria to obtain pertinent studies and to increase the chance of finding a valid conclusion. The pooled prevalence and OR obtained in this meta-analysis were calculated from studies that detected EBV infection with the ISH method. All studies that investigated the presence of EBV by other methods, including different types of PCR assays, and even immunohistochemistry (IHC), did not consider in our analysis. The reason for this stems from the fact that the sensitivity and specificity of each detection method are different, and it is not reliable to draw a conclusion using the pooled data.

The gold standard technique for the detection of EBV in tissues is ISH with EBV EBERs (EBER-ISH) due to its high sensitivity and specificity to determine the precise intranuclear localization of the EBV-infected cells. The diagnosis of EBV-associated gastric cancer is confirmed by the presence of EBER within the tumor cells and its absence in the normal tissue adjacent to the tumor [3]. Many studies have reported the higher prevalence of EBV among gastric cancer patients by PCR assay than the EBER-ISH technique [17]. However, PCR is unable to discriminate between cancer cells and lymphocytes infiltrating in tumor stromal, and thus it is impossible to know from where the EBV genome is amplified. It should be noted that the vast majority of people (nearly $90 \%$ ) are EBV carriers, and their lymphocytes probably contain EBV genomes [11]. Regarding the statements above, our meta-analysis exclusively focused on the positivity of the EBV-associated gastric cancers by ISH only.

One of the major strong points in this meta-analysis is that the pooled estimate of ORs was calculated from studies with matched pairs and non-matched pairs designs, separately, with different statistical methods. The detailed descriptions about the analysis of data for matched pairs and non-matched pairs 
studies are available in several previous studies [96]. It has been recommended that a matched-pairs analysis should be used to assess effect sizes for studies with matched pairs design. Accordingly, the pooled OR determined for studies with non-matched pairs and matched pairs designs were 3.31 (95\% Cl: $0.95-11.54 ; I^{2}=55.0 \%$ ) and 18.56 (95\% Cl: $\left.15.68-21.97 ; I^{2}=55.4 \%\right)$, respectively. We performed two separate analyses for studies with match pairs and non-match pairs designs to demonstrate that the strength of association (ORs) between EBV infection and gastric cancer is the highest when tumoradjacent normal tissues are used as a control group. This is due to the fact that confounding variables are eliminated from data analysis. Therefore, we can obtain more accurate and robust estimates of the association between EBV and gastric cancer. This finding of our study will be beneficial for researchers to design their future case-control studies appropriately. Using the tumor-adjacent normal tissues as the control group will provide more accurate results regarding the relationship between EBV infection and gastric cancer.

To date, several studies have attempted to discover the role of EBV infection in gastric cancer progression. EBV enters $B$ lymphocytes in oropharyngeal lymphoid tissues. The virus then enters the gastric epithelial cells, either by the cell-to-cell contact between B lymphocytes and gastric epithelial cells or by direct entry into the gastric epithelia [97]. It has been reported that EBV entry into the gastric epithelial cells is facilitated by the previous mucosal damage [66]. After the virus enters the cell, EBV establishes type I latency in which a limited set of the latent gene is expressed [77]. A recent systematic review study showed that the most of the EBV latent proteins expressed in gastric cancer cases were EBNA1 (98.1\%) and LMP2A (53.8\%), whereas LMP1 and LMP2B were detected in only 10\% of EBVassociated gastric cancer cases. Some of the lytic proteins, such as BARF1, were also reported to be present in almost half of EBV-associated gastric cancer cases [98]. It is shown that the EBV-encoded BARF1 acts as an oncogene and promotes cell proliferation in gastric cancer through upregulation of NFKB signaling and reduction of the cell cycle inhibitor p21 [99]. It is well known that DNA methylation plays a crucial role in gastric cancer development and progression [100]. Methylation of both viral and cellular genome is one of the critical mechanisms involved in the development and maintenance of EBVassociated gastric cancer. It is well documented that EBV latent membrane protein 2A (LMP2A) plays a variety of key roles in the epigenetic abnormalities such as aberrant DNA methylation in host stomach cells, and the development and maintenance of EBV-associated gastric cancer [9].

Another interesting finding of our meta-analysis is that the prevalence of EBV was 1.9-fold higher in male patients than in female patients with gastric cancer $(P<0.01)$. However, the OR estimate for EBVassociated gastric cancer was significantly higher among females than in males $(P=0.06)$. According to these results, we concluded that women are more likely than men (1.5-fold) to develop EBV-associated gastric cancer. This novel finding can be explained by different genetic backgrounds, lifestyles, or hormonal conditions between the two genders.

Subgroup analyses based on the tumor anatomical location indicate an anatomic preference for EBV during gastric carcinogenesis. Indeed, EBV-associated gastric cancers were significantly more prevalent in the cardia and the body of the stomach than in the antrum $(P<0.01)$ (Table 2). However, the situation 
was different when OR was calculated. So that the OR estimate for EBV-associated gastric cancer was remarkably higher in the antrum than in the cardia and in the body (Table 3), although the difference was not statistically significant. This feature can be justified by the fact that the various parts of the stomach have different physiological conditions.

One prominent finding of the present meta-analysis is that EBV was detected more frequently in biopsy samples than in FFPE specimens from gastric cancer patients (2.4-fold, $P<0.01)$. It is well documented that there are several challenges when working with FFPE samples, such as the low amount of extracted nucleic acids, and fragmentation of genomes and transcripts during the processes of fixation and embedding in paraffin. Therefore, to prevent false-negative results, using biopsy samples is recommended.

According to Lauren's histological classification, gastric carcinoma is classified into two distinct types, namely intestinal and diffuse types. There are many differences between intestinal and diffuse types based on their epidemiology, etiology, and pathology [80]. However, the current meta-analysis showed that the prevalence of EBV was similar in intestinal and diffuse types (8.15\% and $9.40 \%$, respectively), and no significant association of EBV infection with the histological type was found $(P=0.27)$.

Similarly, our results did not indicate any significant difference in the prevalence of EBV-associated gastric cancer among different geographic regions, even between developed and developing countries. The same prevalence in developed and developing countries demonstrates that economic conditions are not related to EBV-associated gastric cancer risk.

There are some limitations in this study arose from the nature of the data sources used in the metaanalysis. Gastric cancer is a multifactorial disease affected by several risk factors. Age is considered as a risk factor for the development of EBV-associated gastric carcinoma. However, the majority of studies included in the current meta-analysis did not categorize EBV-infected and -uninfected gastric cancer patients based on the age group. Subsequently, we were not able to perform a subgroup analysis in this regard. Besides, there are some reports on the association between Helicobacter pylori infection and gastric cancer. Nevertheless, we did not consider data regarding the co-infection of EBV and Helicobacter pylori.

\section{Conclusions}

To sum up, our meta-analysis suggests that the pooled prevalence of EBV among patients with gastric cancer was $8.78 \%$. To determine the association between EBV infection and gastric cancer, a matchedpairs analysis from case-control studies was performed, and the pooled OR was calculated 18.56. This finding indicates a robust positive association between EBV infection and gastric cancer risk. We recommend using biopsy instead of FFPE samples and the ISH technique instead of PCR methods to ensure the validity of results. 
Furthermore, the pooled prevalence of EBV was obtained from data from 27 countries in the world.

Therefore, conducting studies in other geographical regions is strongly recommended to get more reliable estimates. Furthermore, we suggest that researchers use the tumor-adjacent normal tissues as the control group for their case-control studies to achieve more accurate results regarding the relationship between EBV infection and gastric cancer.

\section{Abbreviations}

EBV: Epstein-Barr virus; Cl: confidence interval; OR: odds ratio; EBER: EBV-encoded small RNA; ISH: in situ hybridization; PCR: polymerase chain reaction; FFPE: formalin-fixed paraffin-embedded; ELISA: enzyme-linked immunosorbent assay; PBMC: peripheral blood mononuclear cell; IHC: Immunohistochemistry; LMP: Latent membrane protein; BARF-1: BamH1-A Reading Frame-1; NF-kB: nuclear factor kappa B; EBNA-1: Epstein-Barr nuclear antigen 1.

\section{Declarations}

\section{Ethics approval and consent to participate}

Not applicable

\section{Consent for publication}

Not applicable

\section{Availability of data and materials}

All data generated or analyzed during this study are included in this article.

\section{Competing interests}

The authors have no conflict of interest.

\section{Funding}

This study was not financially supported by any individual, agency, or institution.

\section{Authors 'contributions}

A.T and M.F designed the study. M.F performed the statistical analysis. A.T wrote, reviewed, and edited the manuscript. SH. M and SJ. K performed data interpretation. A.T, M.F, S.A, and F.S.M performed search strategy. All authors involved in the acquisition of data, read and approved the final draft.

\section{Acknowledgments}

Not applicable. 


\section{References}

1. Bray F, Ferlay J, Soerjomataram I, Siegel RL, Torre LA, Jemal A. Global cancer statistics 2018: GLOBOCAN estimates of incidence and mortality worldwide for 36 cancers in 185 countries. CA Cancer J Clin. 2018;68(6):394-424.

2. BenAyed-Guerfali D, Ayadi W, Miladi-Abdennadher I, Khabir A, Sellami-Boudawara T, Gargouri A, et al. Characteristics of epstein barr virus variants associated with gastric carcinoma in Southern Tunisia. Virol J. 2011;8(1):1-9.

3. Ribeiro J, Oliveira A, Malta M, Oliveira C, Silva F, Galaghar A, et al. Clinical and pathological characterization of Epstein-Barr virus-associated gastric carcinomas in Portugal. World $\mathrm{J}$ Gastroenterol. 2017;23(40):7292-7302.

4. Burke A, Yen T, Shekitka K, Sobin L. Lymphoepithelial carcinoma of the stomach with Epstein-Barr virus demonstrated by polymerase chain reaction. Mod Pathol. 1990;3(3):377-380.

5. Shibata D, Weiss L. Epstein-Barr virus-associated gastric adenocarcinoma. Am J Pathol. 1992;140(4):769-774.

6. lizasa H, Nanbo A, Nishikawa J, Jinushi M, Yoshiyama H. Epstein-Barr Virus (EBV)-associated gastric carcinoma. Viruses. 2012;4(12):3420-3439.

7. Kang W, To KF. Are Epstein-Barr Virus-positive and-negative Gastric Carcinomas, With Lymphoid Stroma, Single Entity or Different Entities? Clin Gastroenterol Hepatol. 2015;13(10):1745-1747.

8. Shinozaki-Ushiku A, Kunita A, Fukayama M. Update on Epstein-Barr virus and gastric cancer. Int J Oncol. 2015;46(4):1421-1434.

9. Nishikawa J, lizasa H, Yoshiyama H, Shimokuri K, Kobayashi Y, Sasaki S, et al. Clinical Importance of Epstein-Barr Virus-Associated Gastric Cancer. Cancers. 2018;10(6):1-13.

10. Deyhimi P, Kalantari M. Study of Epstein-Barr virus expression in Burkitt's lymphoma by polymerase chain reaction and in situ hybridization: A study in Iran. Dent Res J. 2014;11(3):380-385.

11. Chen X-Z, Chen H, Castro FA, Hu J-K, Brenner H. Epstein-Barr virus infection and gastric cancer: a systematic review. Medicine. 2015;94(20):1-9.

12. Murphy G, Pfeiffer R, Camargo MC, Rabkin CS. Meta-analysis shows that prevalence of Epstein-Barr virus-positive gastric cancer differs based on sex and anatomic location. Gastroenterology. 2009;137(3):824-833.

13. Li S, Du H, Wang Z, Zhou L, Zhao X, Zeng Y. Meta-analysis of the relationship between Epstein-Barr virus infection and clinicopathological features of patients with gastric carcinoma. Sci China Life Sci. 2010;53(4):524-530.

14. Lee JH, Kim SH, Han SH, An JS, Lee ES, Kim YS. Clinicopathological and molecular characteristics of Epstein-Barr virus-associated gastric carcinoma: A meta-analysis. J Gastroenterol Hepatol. 2009;24(3):354-365.

15. Sousa H, Pinto-Correia AL, Medeiros R, Dinis-Ribeiro M. Epstein-Barr virus is associated with gastric carcinoma: the question is what is the significance? World J Gastroenterol. 2008;14(27): 4347-4351. 
16. Camargo M, Murphy G, Koriyama C, Pfeiffer R, Kim WH, Herrera-Goepfert R, et al. Determinants of Epstein-Barr virus-positive gastric cancer: an international pooled analysis. $\mathrm{Br} \mathrm{J}$ Cancer. 2011;105(1):38-43.

17. Bae J-M, Kim EH. Epstein-Barr virus and gastric cancer risk: a meta-analysis with meta-regression of case-control studies. J Prev Med Public Health. 2016;49(2): 97-107.

18. Moher D, Liberati A, Tetzlaff J, Altman DG. Preferred reporting items for systematic reviews and meta-analyses: the PRISMA statement. Ann Intern Med. 2009;151(4):264-269.

19. DerSimonian R, Laird N. Meta-analysis in clinical trials. Control Clin Trials. 1986;7(3):177-188.

20. Newcombe RG. Two-sided confidence intervals for the single proportion: comparison of seven methods. Stat Med. 1998;17(8):857-872.

21. Higgins JP, Thompson SG, Deeks JJ, Altman DG. Measuring inconsistency in meta-analyses. Bmj. 2003;327(7414):557-560.

22. Begg CB, Mazumdar M. Operating characteristics of a rank correlation test for publication bias. Biometrics. 1994;50(4):1088-1101.

23. R Core Team (2018). R: A language and environment for statistical computing. R Foundation for Statistical Computing, Vienna, Austria. https://www.R-project.org.

24. Schwarzer G. meta: An R package for meta-analysis. R news. 2007;7(3):40-45.

25. Viechtbauer W. Conducting meta-analyses in R with the metafor package. J Stat Softw. 2010;36(3):148.

26. Rowlands D, Ito M, Mangham D, Reynolds G, Herbst $H$, Hallissey M, et al. Epstein-Barr virus and carcinomas: rare association of the virus with gastric adenocarcinomas. $\mathrm{Br} \mathrm{J}$ Cancer. 1993;68(5):1014-1019.

27. Shibata D, Hawes D, Stemmermann GN, Weiss LM. Epstein-Barr virus-associated gastric adenocarcinoma among Japanese Americans in Hawaii. Cancer Epidemiol Biomarkers Prev. 1993;2(3):213-217.

28. Tokunaga $M$, Uemura $Y$, Tokudome $T$, Ishidate $T$, Masuda H, Okazaki E, et al. Epstein-Barr virus related gastric cancer in Japan: a molecular patho-epidemiological study. Pathol Int. 1993;43(10):574-581.

29. Tokunaga M, Land C, Uemura Y, Tokudome T, Tanaka S, Sato E. Epstein-Barr virus in gastric carcinoma. Am J Pathol. 1993;143(5):1250-1254.

30. Imai S, Koizumi S, Sugiura M, Tokunaga M, Uemura Y, Yamamoto N, et al. monoclonal epithelial malignant cells expressing Epstein-Barr virus latent infection protein. Proc Natl Acad Sci. 1994;91(19):9131-9135.

31. Ott G, Kirchner T, Müller-Hermelink H. Monoclonal Epstein-Barr virus genomes but lack of EBV-related protein expression in different types of gastric carcinoma. Histopathology. 1994;25(4):323-329.

32. Shousha S, Luqmani Y. Epstein-Barr virus in gastric carcinoma and adjacent normal gastric and duodenal mucosa. J Clin Pathol. 1994;47(8):695-698. 
33. Yuen S, Chung L, Leung S, Luk I, Chan S, Ho J. In situ detection of Epstein-Barr virus in gastric and colorectal adenocarcinomas. Am J Surg Pathol. 1994;18(11):1158-1163.

34. Harn H-J, Chang J-Y, Wang M-W, Ho L-I, Lee H-S, Chiang J-H, et al. Epstein-Barr virus-associated gastric adenocarcinoma in Taiwan. Hum Pathol. 1995;26(3):267-271.

35. Gulley ML, Pulitzer DR, Eagan PA, Schneider BG. Epstein-Barr virus infection is an early event in gastric carcinogenesis and is independent of bcl-2 expression and p53 accumulation. Hum Pathol. 1996;27(1):20-27.

36. Moritani S, Kushima R, Sugihara H, Hattori T. Phenotypic characteristics of Epstein-Barr-virusassociated gastric carcinomas. J Cancer Res Clin Oncol. 1996;122(12):750-756.

37. Selves J, Bibeau F, Brousset P, Meggetto F, Mazerolles C, Voigt JJ, et al. Epstein-Barr virus latent and replicative gene expression in gastric carcinoma. Histopathology. 1996;28(2):121-127.

38. Shin WS, Kang MW, Kang JH, Choi MK, Ahn BM, Kim JK, et al. Epstein-Barr virus-associated gastric adenocarcinomas among Koreans. Am J Clin Pathol. 1996;105(2):174-181.

39. Galetsky SA, Tsvetnov VV, Land CE, Afanasieva TA, Petrovichev NN, Gurtsevitch VE, et al. EpsteinBarr-virus-associated gastric cancer in Russia. Int J Cancer. 1997;73(6):786-789.

40. Clark GD, Lee YS, Min K-W, Dunn ST. Epstein-Barr Virus in Gastric Carcinomas from Singapore. Int J Surg Pathol. 1996;4(3):149-158.

41. Ojima H, Fukuda T, Nakajima T, Nagamachi Y. Infrequent overexpression of p53 protein in EpsteinBarr virus-associated gastric carcinomas. Jpn J Canc Res. 1997;88(3):262-266.

42. Yanai H, Nishikawa J, Mizugaki Y, Shimizu N, Takada K, Matsusaki K, et al. Endoscopic and pathologic features of Epstein-Barr virus-associated gastric carcinoma. Gastrointest Endosc. 1997;45(3):236-242.

43. Herrera-Goepfert R, Reyes E, Hernández-Avila M, Mohar A, Shinkura R, Fujiyama C, et al. Epstein-Barr virus-associated gastric carcinoma in Mexico: analysis of 135 consecutive gastrectomies in two hospitals. Mod Pathol. 1999;12(9):873-878.

44. Kume T, Oshima K, Shinohara T, Takeo H, Yamashita Y, Shirakusa T, et al. Low rate of apoptosis and overexpression of bcl-2 in Epstein-Barr virus-associated gastric carcinoma. Histopathology. 1999;34(6):502-509.

45. Takano Y, Kato Y, Saegusa M, Mori S, Shiota M, Masuda M, et al. The role of the Epstein-Barr virus in the oncogenesis of EBV (+) gastric carcinomas. Virchows Arch. 1999;434(1):17-22.

46. Wan R, Gao M-Q, Gao L-Y, Chen B-F, Cai Q-K. In situ detection of Epstein-Barr virus in gastric carcinoma tissue in China highrisk area. World J Gastroenterol. 1999;5(6):531-532.

47. Chapel F, Fabiani B, Davi F, Raphael M, Tepper M, Champault G, et al. Epstein-Barr virus and gastric carcinoma in Western patients: comparison of pathological parameters and p53 expression in EBVpositive and negative tumours. Histopathology. 2000;36(3):252-261.

48. Wu MS, Shun CT, Wu CC, Hsu TY, Lin MT, Chang MC, et al. Epstein-Barr virus-associated gastric carcinomas: Relation to H. pylori infection and genetic alterations. Gastroenterology. 
2000;118(6):1031-1038.

49. Corvalan A, Koriyama C, Akiba S, Eizuru Y, Backhouse C, Palma M, et al. Epstein-Barr virus in gastric carcinoma is associated with location in the cardia and with a diffuse histology: A study in one area of Chile. Int J Cancer. 2001;94(4):527-530.

50. Kijima Y, Hokita S, Takao S, Baba M, Natsugoe S, Yoshinaka H, et al. Epstein-Barr virus involvement is mainly restricted to lymphoepithelial type of gastric carcinoma among various epithelial neoplasms. J Med Virol. 2001;64(4):513-518.

51. Ishii H, Gobe G, Kawakubo Y, Sato Y, Ebihara Y. Interrelationship between Epstein-Barr virus infection in gastric carcinomas and the expression of apoptosis-associated proteins. Histopathology. 2001;38(2):111-119.

52. Koriyama C, Akiba S, Iriya K, Yamaguti T, Hamada GS, Itoh T, et al. Epstein-Barr virus-associated gastric carcinoma in Japanese Brazilians and non-Japanese Brazilians in Sao Paulo. Jpn J Canc Res. 2001;92(9):911-917.

53. Luqmani YA, Linjawi SO, Shousha S. Detection of Epstein-Barr virus in gastrectomy specimens. Oncol Rep. 2001;8(5):995-999.

54. Burgess D, Woodman C, Flavell K, Rowlands D, Crocker J, Scott K, et al. Low prevalence of EpsteinBarr virus in incident gastric adenocarcinomas from the United Kingdom. Br J Cancer. 2002;86(5):702-704.

55. Kang GH, Lee S, Kim WH, Lee HW, Kim JC, Rhyu M-G, et al. Epstein-barr virus-positive gastric carcinoma demonstrates frequent aberrant methylation of multiple genes and constitutes CpG island methylator phenotype-positive gastric carcinoma. Am J Pathol. 2002;160(3):787-794.

56. Kattoor J, Koriyama C, Akiba S, Itoh T, Ding S, Eizuru Y, et al. Epstein-Barr virus-associated gastric carcinoma in southern India: A comparison with a large-scale Japanese series. J Med Virol. 2002;68(3):384-389.

57. Vo Q, Geradts J, Gulley M, Boudreau D, Bravo J, Schneider B. Epstein-Barr virus in gastric adenocarcinomas: association with ethnicity and CDKN2A promoter methylation. J Clin Pathol. 2002;55(9):669-675.

58. Czopek JP, Stojak M, Sińczak A, Popiela T, Kulig J, Rudzki Z, et al. EBV-positive gastric carcinomas in Poland. Pol J Pathol. 2003;54(2):123-128.

59. Karim N, Pallesen G. Epstein-Barr virus (EBV) and gastric carcinoma in Malaysian patients. Malays J Pathol. 2003;25(1):45-47.

60. Oda K, Koda K, Takiguchi N, Nunomura M, Seike K, Miyazaki M. Detection of Epstein-Barr virus in gastric carcinoma cells and surrounding lymphocytes. Gastric Cancer. 2003;6(3):173-178.

61. Ishii H, Gobe G, Yoneyama J, Mukaide M, Ebihara Y. Role of p53, apoptosis, and cell proliferation in early stage Epstein-Barr virus positive and negative gastric carcinomas. J Clin Pathol. 2004;57(12):1306-1311.

62. Lee HS, Chang MS, Yang H-K, Lee BL, Kim WH. Epstein-Barr virus-positive gastric carcinoma has a distinct protein expression profile in comparison with Epstein-Barr virus-negative carcinoma. Clin 
Cancer Res. 2004;10(5):1698-1705.

63. Lopes L, Bacchi MM, Elgui-de-Oliveira D, Zanati S, Alvarenga M, Bacchi CE. Epstein-Barr virus infection and gastric carcinoma in São Paulo State, Brazil. Braz J Med Biol Res. 2004;37(11):17071712.

64. van Beek J, Zur Hausen A, Klein Kranenbarg E, van de Velde CJ, Middeldorp JM, van den Brule AJ, et al. EBV-positive gastric adenocarcinomas: a distinct clinicopathologic entity with a low frequency of lymph node involvement. J Clin Oncol. 2004;22(4):664-670.

65. Alipov G, Nakayama T, Nakashima M, Wen C-Y, Niino D, Kondo H, et al. Epstein-Barr virus-associated gastric carcinoma in Kazakhstan. World J Gastroenterol. 2005;11(1):27-30.

66. Herrera-Goepfert R, Akiba S, Koriyama C, Ding S, Reyes E, Itoh T, et al. Epstein-Barr virus-associated gastric carcinoma: Evidence of age-dependence among a Mexican population. World J Gastroenterol. 2005;11(39):6096-6103.

67. Luo B, Wang Y, Wang X-F, Liang H, Yan L-P, Huang B-H, et al. Expression of Epstein-Barr virus genes in EBV-associated gastric carcinomas. World J Gastroenterol. 2005;11(5): 629-633.

68. Yoshiwara E, Koriyama C, Akiba S, Itoh T, Minakami Y, Chirinos J, et al. Epstein-Barr virus-associated gastric carcinoma in Lima, Peru. J Exp Clin Cancer Res. 2005;24(1):49-54.

69. Campos Fl, Koriyama C, Akiba S, Carrasquilla G, Serra M, Carrascal E, et al. Environmental factors related to gastric cancer associated with Epstein-Barr virus in Colombia. Asian Pac J Cancer Prev. 2006;7(4):633-637.

70. Szkaradkiewicz A, Majewski W, Wal M, Czyżak M, Majewski P, Bierła J, et al. Epstein-Barr virus (EBV) infection and p53 protein expression in gastric carcinoma. Virus Res. 2006;118(1-2):115-119.

71. Luo B, Wang Y, Wang X-F, Gao Y, Huang B-H, Zhao P. Correlation of Epstein-Barr virus and its encoded proteins with Helicobacter pylori and expression of c-met and c-myc in gastric carcinoma. World J Gastroenterol. 2006;12(12):1842-1848.

72. von Rahden BH, Langner C, Brücher BL, Stein HJ, Sarbia M. No association of primary adenocarcinomas of the small bowel with Epstein-Barr virus infection. Mol Carcinog. 2006;45(5):349-352.

73. Abdirad A, Ghaderi-Sohi S, Shuyama K, Koriyama C, Nadimi-Barforoosh H, Emami S, et al. EpsteinBarr virus associated gastric carcinoma: a report from Iran in the last four decades. Diagn Pathol. 2007;2(1):1-9.

74. Jung IM, Chung JK, Kim YA, Kim JE, Heo SC, Ahn YJ, et al. Epstein-Barr virus, beta-catenin, and Ecadherin in gastric carcinomas. J Korean Med Sci. 2007;22(5):855-861.

75. Lima VP, de Lima MAP, André AR, Ferreira MVP, Barros MAP, Rabenhorst SHB. H pylori (CagA) and Epstein-Barr virus infection in gastric carcinomas: correlation with p53 mutation and c-Myc, Bcl-2 and Bax expression. World J Gastroenterol. 2008;14(6):884-891.

76. Ryan JL, Morgan DR, Dominguez RL, Thorne LB, Elmore SH, Mino-Kenudson M, et al. High levels of Epstein-Barr virus DNA in latently infected gastric adenocarcinoma. Lab Invest. 2009;89(1):80-90. 
77. Trimeche M, Ksiâa F, Ziadi S, Mestiri S, Hachana M, Gacem RB, et al. Prevalence and characteristics of Epstein-Barr virus-associated gastric carcinomas in Tunisia. Eur J Gastroenterol Hepatol. 2009;21(9):1001-1007.

78. Truong CD, Feng W, Li W, Khoury T, Li Q, Alrawi S, et al. Characteristics of Epstein-Barr virusassociated gastric cancer: a study of 235 cases at a comprehensive cancer center in USA. J Exp Clin Cancer Res. 2009;28(1):1-9.

79. Ferrasi AC, Pinheiro NA, Rabenhorst SHB, Caballero OL, Rodrigues MAM, Carvalho F, et al. Helicobacter pylori and EBV in gastric carcinomas: methylation status and microsatellite instability. World J Gastroenterol. 2010;16(3):312-319.

80. Koriyama C, Akiba S, Shimaoka S, Itoh T, Akiyama S-I, Eizuru Y. Frequent expression of thymidine phosphorylase in Epstein-Barr virus-associated gastric carcinoma of diffuse type. Anticancer Res. 2010;30(6):2431-2437.

81. Chen JN, Ding YG, Feng ZY, Li HG, He D, Du H, et al. Association of distinctive Epstein-Barr virus variants with gastric carcinoma in Guangzhou, southern China. J Med Virol. 2010;82(4):658-667.

82. Boysen T, Friborg J, Stribolt K, Hamilton-Dutoit S, Goertz S, Wohlfahrt J, et al. Epstein-Barr virusassociated gastric carcinoma among patients with pernicious anemia. Int $\mathrm{J}$ Cancer. 2011;129(11):2756-2760.

83. Lima MAPd, Ferreira MVP, Barros MAP, Pardini MIdMC, Ferrasi AC, Rabenhorst SHB. Epstein-Barr virus-associated gastric carcinoma in Brazil: comparison between in situ hybridization and polymerase chain reaction detection. Braz J Microbiol. 2012, 43(1):393-404.

84. Ksiaa F, Ziadi S, Gacem R, Dhiab M, Trimeche M. Correlation between DNA methyltransferases expression and Epstein-Barr virus, JC polyomavirus and Helicobacter pylori infections in gastric carcinomas. Neoplasma. 2014, 61(6):710-717.

85. Aslane M, Al Haj A, Henneb A, Khenchouche A, Houali K. Characteristics of gastric carcinoma associated with Epstein Barr virus in Algeria. Der Pharmacia Lettre. 2016;8 (17):169-178.

86. Tsai CY, Liu YY, Liu KH, Hsu JT, Chen TC, Chiu CT, et al. Comprehensive profiling of virus microRNAs of Epstein-Barr virus-associated gastric carcinoma: highlighting the interactions of ebv-Bart9 and host tumor cells. J Gastroenterol Hepatol. 2017;32(1):82-91.

87. Zhang Z-X, Guo D-L, Jin M, Zhang W, Huang L-H, Zhang J-B, et al. Invasion-related signal pathways in Epstein-Barr virus (EBV)-associated gastric carcinoma. Int J Clin Exp Med. 2016;9(2):3544-3550.

88. Liu Y, Yang W, Pan Y, Ji J, Lu Z, Ke Y. Genome-wide analysis of Epstein-Barr virus (EBV) isolated from EBV-associated gastric carcinoma (EBVaGC). Oncotarget. 2016;7(4): 4903-4914.

89. Na SJ, Park HL, Lee SY, Song KY, Kim SH. Correlation Between Infection Status of Epstein-Barr Virus and 18F-Fluorodeoxyglucose Uptake in Patients with Advanced Gastric Cancer. in vivo. 2017;31(4):749-753.

90. Böger C, Krüger S, Behrens H, Bock S, Haag J, Kalthoff H, et al. Epstein-Barr virus-associated gastric cancer reveals intratumoral heterogeneity of PIK3CA mutations. Ann Oncol. 2017;28(5):1005-1014. 
91. Kim JY, Bae BN, Kang G, Kim HJ, Park K. Cytokine expression associated with Helicobacter pylori and Epstein-Barr virus infection in gastric carcinogenesis. Apmis. 2017;125(9):808-815.

92. Nogueira C, Mota M, Gradiz R, Cipriano MA, Caramelo F, Cruz H, et al. Prevalence and characteristics of Epstein-Barr virus-associated gastric carcinomas in Portugal. Infect Agent Cancer. 2017;12(1):1-8.

93. de Souza CRT, Almeida MCA, Khayat AS, da Silva EL, Soares PC, Chaves LC, et al. Association between Helicobacter pylori, Epstein-Barr virus, human papillomavirus and gastric adenocarcinomas. World J Gastroenterol. 2018;24(43): 4928-4938.

94. Wanvimonsuk S, Thitiwanichpiwong P, Keelawat S, Mutirangura A, Kitkumthorn N. Distribution of the Epstein-Barr virus in the normal stomach and gastric lesions in Thai population. J Med Virol. 2019;91(3):444-449.

95. Martinez-Ciarpaglini C, Fleitas-Kanonnikoff T, Gambardella V, Llorca M, Mongort C, Mengual R, et al. Assessing molecular subtypes of gastric cancer: microsatellite unstable and Epstein-Barr virus subtypes. Methods for detection and clinical and pathological implications. ESMO open. 2019;4(3):18.

96. Dunlap WP, Cortina JM, Vaslow JB, Burke MJ. Meta-analysis of experiments with matched groups or repeated measures designs. Psychol Methods. 1996;1(2):170-177.

97. Yue W, Zhu M, Zuo L, Xin S, Zhang J, Liu L, et al. Early Pattern of Epstein-Barr Virus Infection in Gastric Epithelial Cells by “Cell-in-cell”. Virol Sin. 2019;34(3):253-261.

98. Ribeiro J, Oliveira C, Malta M, Sousa H. Epstein-Barr virus gene expression and latency pattern in gastric carcinomas: a systematic review. Future Oncol. 2017;13(6):567-579.

99. Chang MS, Kim DH, Roh JK, Middeldorp JM, Kim YS, Kim S, et al. Epstein-Barr virus-encoded BARF1 promotes proliferation of gastric carcinoma cells through regulation of NF-kB. J Virol. 2013;87(19):10515-10523.

100. Tahara T, Arisawa T. DNA methylation as a molecular biomarker in gastric cancer. Epigenomics. 2015;7(3):475-486.

\section{Table 1}

Table 1. Characteristics of the included studies in this systematic review and meta-analysis 


\begin{tabular}{|c|c|c|c|c|c|c|c|c|}
\hline Author [Ref.] & Year & Location & $\begin{array}{l}\text { Study } \\
\text { design }\end{array}$ & $\begin{array}{l}\text { Type of } \\
\text { sample }\end{array}$ & $\begin{array}{l}\text { No. of } \\
\text { case }\end{array}$ & $\begin{array}{l}\text { No. of } \\
\text { control }\end{array}$ & $\begin{array}{l}\text { No. of case } \\
\text { positive }\end{array}$ & $\begin{array}{l}\text { No. of control } \\
\text { positive }\end{array}$ \\
\hline Rowlands [26] & 1993 & $\begin{array}{l}\text { UK and } \\
\text { Japan }\end{array}$ & $\begin{array}{l}\text { Cross- } \\
\text { sectional }\end{array}$ & FFPE & 174 & & 9 & \\
\hline Shibata [27] & 1993 & USA & $\begin{array}{c}\text { Cross- } \\
\text { sectional }\end{array}$ & FFPE & 187 & & 19 & \\
\hline Tokunaga [28] & 1993 & Japan & $\begin{array}{c}\text { Cross- } \\
\text { sectional }\end{array}$ & FFPE & 1848 & & 122 & \\
\hline Tokunaga [29] & 1993 & Japan & $\begin{array}{c}\text { Cross- } \\
\text { sectional }\end{array}$ & FFPE & 999 & & 69 & \\
\hline Imai [30] & 1994 & Japan & $\begin{array}{l}\text { Case- } \\
\text { control }\end{array}$ & FFPE & 1000 & 1000 & 70 & 0 \\
\hline Ott [31] & 1994 & Germany & $\begin{array}{l}\text { Case- } \\
\text { control }\end{array}$ & FFPE & 39 & 39 & 7 & 0 \\
\hline Shousha [32] & 1994 & UK & $\begin{array}{l}\text { Case- } \\
\text { control }\end{array}$ & FFPE & 19 & 9 & 1 & 5 \\
\hline Yuen [33] & 1994 & China & $\begin{array}{l}\text { Case- } \\
\text { control }\end{array}$ & FFPE & 74 & 36 & 7 & 0 \\
\hline Harn [34] & 1995 & Taiwan & $\begin{array}{l}\text { Case- } \\
\text { control }\end{array}$ & FFPE & 55 & 49 & 6 & 0 \\
\hline Gulley [35] & 1996 & USA & $\begin{array}{l}\text { Case- } \\
\text { control }\end{array}$ & FFPE & 95 & 95 & 11 & 0 \\
\hline Moritani [36] & 1996 & Japan & $\begin{array}{c}\text { Case- } \\
\text { control }\end{array}$ & FFPE & 132 & 132 & 15 & 0 \\
\hline Selves [37] & 1996 & France & $\begin{array}{l}\text { Case- } \\
\text { control }\end{array}$ & FFPE & 59 & 59 & 5 & 0 \\
\hline Shin [38] & 1996 & South Korea & $\begin{array}{c}\text { Case- } \\
\text { control }\end{array}$ & FFPE & 89 & 37 & 12 & 0 \\
\hline Galetsky [39] & 1997 & Russia & $\begin{array}{c}\text { Case- } \\
\text { control }\end{array}$ & FFPE & 206 & 206 & 18 & 0 \\
\hline Clark [40] & 1997 & Singapore & $\begin{array}{l}\text { Cross- } \\
\text { sectional }\end{array}$ & FFPE & 137 & & 6 & \\
\hline Ojima [41] & 1997 & Japan & $\begin{array}{l}\text { Cross- } \\
\text { sectional }\end{array}$ & FFPE & 412 & & 83 & \\
\hline Yanai [42] & 1997 & Japan & $\begin{array}{c}\text { Cross- } \\
\text { sectional }\end{array}$ & FFPE & 124 & & 12 & \\
\hline $\begin{array}{c}\text { Herrera-Goepfert } \\
{[43]}\end{array}$ & 1999 & Mexico & $\begin{array}{c}\text { Cross- } \\
\text { sectional }\end{array}$ & FFPE & 135 & & 11 & \\
\hline Kume [44] & 1999 & Japan & $\begin{array}{l}\text { Case- } \\
\text { control }\end{array}$ & FFPE & 344 & 344 & 40 & 0 \\
\hline Takano [45] & 1999 & Japan & $\begin{array}{c}\text { Cross- } \\
\text { sectional }\end{array}$ & FFPE & 513 & & 33 & \\
\hline Wan [46] & 1999 & China & $\begin{array}{c}\text { Case- } \\
\text { control }\end{array}$ & FFPE & 58 & 58 & 6 & 0 \\
\hline Chapel [47] & 2000 & France & $\begin{array}{c}\text { Case- } \\
\text { control }\end{array}$ & FFPE & 56 & 56 & 7 & 0 \\
\hline Wu [48] & 2000 & Taiwan & $\begin{array}{c}\text { Cross- } \\
\text { sectional }\end{array}$ & Biopsy & 150 & & 30 & \\
\hline Corvalan [49] & 2001 & Chile & $\begin{array}{c}\text { Case- } \\
\text { control }\end{array}$ & FFPE & 185 & 185 & 31 & 0 \\
\hline Kijima [50] & 2001 & Japan & Cross- & FFPE & 313 & & 23 & \\
\hline
\end{tabular}




\begin{tabular}{|c|c|c|c|c|c|c|c|c|}
\hline & & & sectional & & & & & \\
\hline Ishii [51] & 2001 & Japan & $\begin{array}{c}\text { Cross- } \\
\text { sectional }\end{array}$ & FFPE & 119 & & 23 & \\
\hline Koriyama [52] & 2001 & Brazil & $\begin{array}{l}\text { Cross- } \\
\text { sectional }\end{array}$ & FFPE & 300 & & 24 & \\
\hline Luqmani [53] & 2001 & UK & $\begin{array}{l}\text { Case- } \\
\text { control }\end{array}$ & FFPE & 20 & 79 & 1 & 9 \\
\hline Burgess [54] & 2002 & UK & $\begin{array}{c}\text { Cross- } \\
\text { sectional }\end{array}$ & FFPE & 534 & & 9 & \\
\hline Kang [55] & 2002 & South Korea & $\begin{array}{c}\text { Cross- } \\
\text { sectional }\end{array}$ & FFPE & 233 & & 21 & \\
\hline Kattoor [56] & 2002 & $\begin{array}{l}\text { India and } \\
\text { Japan }\end{array}$ & $\begin{array}{l}\text { Cross- } \\
\text { sectional }\end{array}$ & FFPE & 2226 & & 135 & \\
\hline Vo [57] & 2002 & USA & $\begin{array}{c}\text { Cross- } \\
\text { sectional }\end{array}$ & FFPE & 107 & & 11 & \\
\hline Czopek [58] & 2003 & Poland & $\begin{array}{c}\text { Cross- } \\
\text { sectional }\end{array}$ & FFPE & 40 & & 5 & \\
\hline Karim [59] & 2003 & Malaysia & $\begin{array}{l}\text { Cross- } \\
\text { sectional }\end{array}$ & FFPE & 50 & & 5 & \\
\hline Oda [60] & 2003 & Japan & $\begin{array}{l}\text { Case- } \\
\text { control }\end{array}$ & FFPE & 97 & 97 & 5 & 0 \\
\hline Ishii [61] & 2004 & Japan & $\begin{array}{l}\text { Case- } \\
\text { control }\end{array}$ & FFPE & 133 & 133 & 19 & 0 \\
\hline Lee [62] & 2004 & South Korea & $\begin{array}{c}\text { Cross- } \\
\text { sectional }\end{array}$ & FFPE & 1127 & & 63 & \\
\hline Lopes [63] & 2004 & Brazil & $\begin{array}{c}\text { Case- } \\
\text { control }\end{array}$ & FFPE & 53 & 53 & 6 & 0 \\
\hline van Beek [64] & 2004 & Netherlands & $\begin{array}{c}\text { Cross- } \\
\text { sectional }\end{array}$ & FFPE & 566 & & 41 & \\
\hline Alipov [65] & 2005 & Kazakhstan & $\begin{array}{c}\text { Case- } \\
\text { control }\end{array}$ & FFPE & 139 & 139 & 14 & 0 \\
\hline $\begin{array}{c}\text { Herrera-Goepfert } \\
{[66]}\end{array}$ & 2005 & Mexico & $\begin{array}{l}\text { Case- } \\
\text { control }\end{array}$ & FFPE & 330 & 330 & 24 & 2 \\
\hline Luo [67] & 2005 & China & $\begin{array}{l}\text { Case- } \\
\text { control }\end{array}$ & FFPE & 172 & 172 & 11 & 0 \\
\hline Yoshiwara [68] & 2005 & Peru & $\begin{array}{l}\text { Cross- } \\
\text { sectional }\end{array}$ & FFPE & 254 & & 10 & \\
\hline Campos [69] & 2006 & Colombia & $\begin{array}{c}\text { Cross- } \\
\text { sectional }\end{array}$ & FFPE & 368 & & 42 & \\
\hline $\begin{array}{c}\text { Szkaradkiewicz } \\
{[70]}\end{array}$ & 2006 & Poland & $\begin{array}{c}\text { Cross- } \\
\text { sectional }\end{array}$ & FFPE & 32 & & 14 & \\
\hline Luo [71] & 2006 & China & $\begin{array}{c}\text { Cross- } \\
\text { sectional }\end{array}$ & FFPE & 185 & & 13 & \\
\hline von Rahden [72] & 2006 & Germany & $\begin{array}{c}\text { Case- } \\
\text { control }\end{array}$ & FFPE & 82 & 82 & 5 & 0 \\
\hline Abdirad [73] & 2007 & Iran & $\begin{array}{c}\text { Cross- } \\
\text { sectional }\end{array}$ & FFPE & 273 & & 9 & \\
\hline Jung [74] & 2007 & South Korea & $\begin{array}{c}\text { Cross- } \\
\text { sectional }\end{array}$ & FFPE & 111 & & 7 & \\
\hline Lima [75] & 2008 & Brazil & $\begin{array}{c}\text { Cross- } \\
\text { sectional }\end{array}$ & FFPE & 71 & & 6 & \\
\hline Ryan [76] & 2009 & USA & Cross- & FFPE & 113 & & 11 & \\
\hline
\end{tabular}




\begin{tabular}{|c|c|c|c|c|c|c|c|c|}
\hline & & & sectional & & & & & \\
\hline Trimeche [77] & 2009 & Tunisia & $\begin{array}{l}\text { Cross- } \\
\text { sectional }\end{array}$ & FFPE & 96 & & 4 & \\
\hline Truong [78] & 2009 & USA & $\begin{array}{c}\text { Case- } \\
\text { control }\end{array}$ & FFPE & 235 & 72 & 12 & 0 \\
\hline Ferrasi [79] & 2010 & Brazil & $\begin{array}{c}\text { Case- } \\
\text { control }\end{array}$ & FFPE & 54 & 54 & 5 & 0 \\
\hline Koriyama [80] & 2010 & Japan & $\begin{array}{c}\text { Cross- } \\
\text { sectional }\end{array}$ & FFPE & 156 & & 21 & \\
\hline Chen [81] & 2010 & China & $\begin{array}{c}\text { Case- } \\
\text { control }\end{array}$ & FFPE & 676 & 676 & 45 & 3 \\
\hline Boysen [82] & 2011 & Denmark & $\begin{array}{l}\text { Cross- } \\
\text { sectional }\end{array}$ & FFPE & 131 & & 10 & \\
\hline $\begin{array}{c}\text { BenAyed-Guerfali } \\
\text { [2] }\end{array}$ & 2011 & Tunisia & $\begin{array}{l}\text { Cross- } \\
\text { sectional }\end{array}$ & FFPE & 81 & & 12 & \\
\hline de Lima [83] & 2012 & Brazil & $\begin{array}{l}\text { Cross- } \\
\text { sectional }\end{array}$ & FFPE & 160 & & 11 & \\
\hline Ksiaa [84] & 2014 & Tunisia & $\begin{array}{l}\text { Cross- } \\
\text { sectional }\end{array}$ & FFPE & 43 & & 4 & \\
\hline Aslane [85] & 2016 & Algeria & $\begin{array}{l}\text { Case- } \\
\text { control }\end{array}$ & FFPE & 97 & 10 & 22 & 0 \\
\hline Tsai [86] & 2016 & Taiwan & $\begin{array}{l}\text { Cross- } \\
\text { sectional }\end{array}$ & FFPE & 1039 & & 52 & \\
\hline Zhang [87] & 2016 & China & $\begin{array}{l}\text { Cross- } \\
\text { sectional }\end{array}$ & FFPE & 600 & & 30 & \\
\hline Liu [88] & 2016 & China & $\begin{array}{c}\text { Case- } \\
\text { control }\end{array}$ & FFPE & 206 & 206 & 15 & 0 \\
\hline $\mathrm{Na}[89]$ & 2017 & South Korea & $\begin{array}{l}\text { Cross- } \\
\text { sectional }\end{array}$ & FFPE & 205 & & 15 & \\
\hline Boger [90] & 2017 & Germany & $\begin{array}{l}\text { Cross- } \\
\text { sectional }\end{array}$ & FFPE & 484 & & 22 & \\
\hline Kim [91] & 2017 & South Korea & $\begin{array}{l}\text { Case- } \\
\text { control }\end{array}$ & FFPE & 207 & 56 & 13 & 0 \\
\hline Nogueira [92] & 2017 & Portugal & $\begin{array}{l}\text { Case- } \\
\text { control }\end{array}$ & FFPE & 82 & 33 & 9 & 1 \\
\hline Ribeiro [3] & 2017 & Portugal & $\begin{array}{l}\text { Cross- } \\
\text { sectional }\end{array}$ & FFPE & 179 & & 15 & \\
\hline de Souza [93] & 2018 & Brazil & $\begin{array}{c}\text { Cross- } \\
\text { sectional }\end{array}$ & Biopsy & 302 & & 62 & \\
\hline $\begin{array}{c}\text { Wanvimonsuk } \\
{[94]}\end{array}$ & 2018 & Thailand & $\begin{array}{c}\text { Case- } \\
\text { control }\end{array}$ & FFPE & 33 & 55 & 4 & 0 \\
\hline $\begin{array}{c}\text { Martinez- } \\
\text { Ciarpaglini [95] }\end{array}$ & 2019 & Spain & $\begin{array}{l}\text { Cross- } \\
\text { sectional }\end{array}$ & FFPE & 209 & & 13 & \\
\hline
\end{tabular}

\section{Figures}




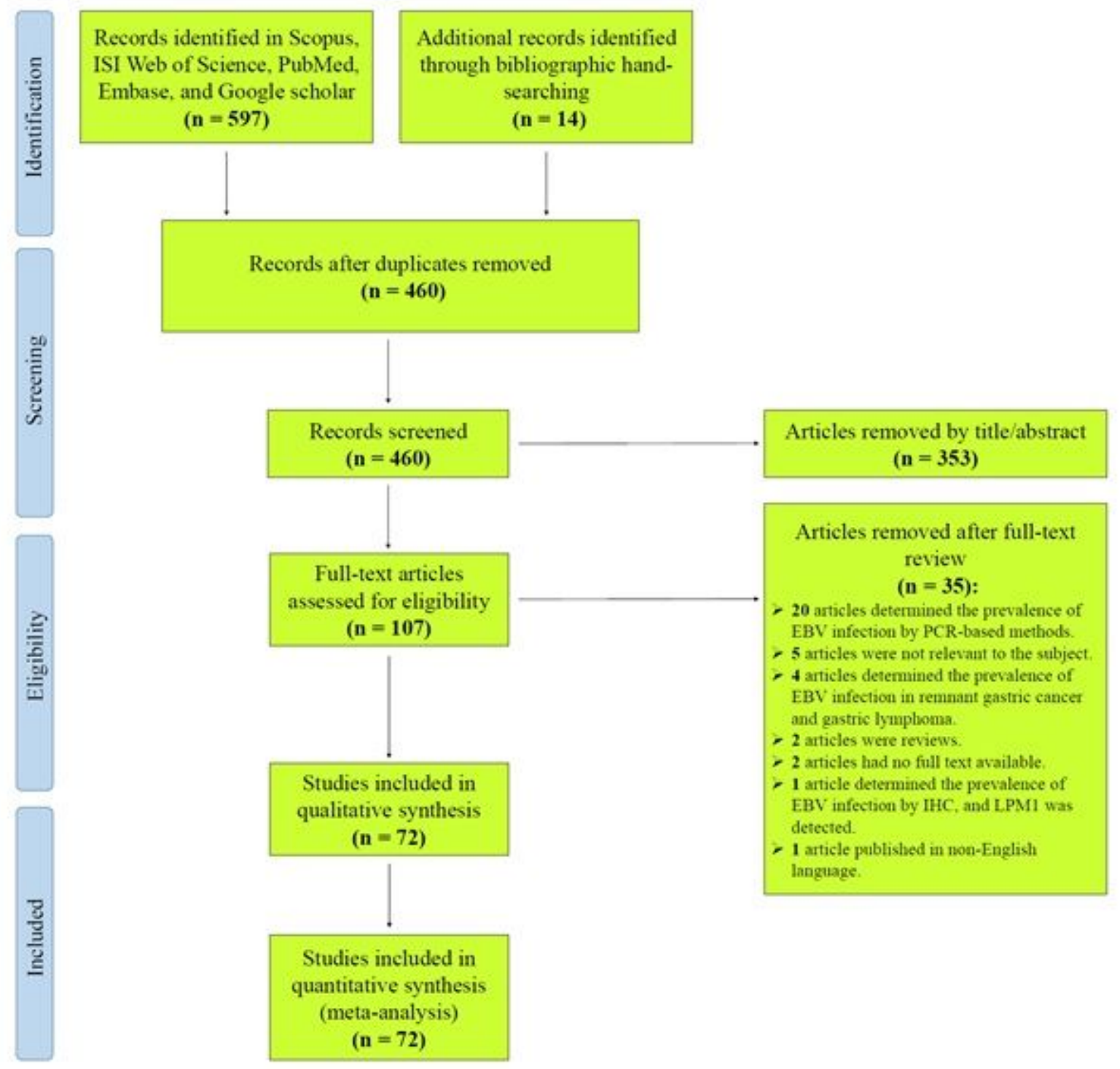

Figure 1

Flowchart presenting the steps of literature search and selection 


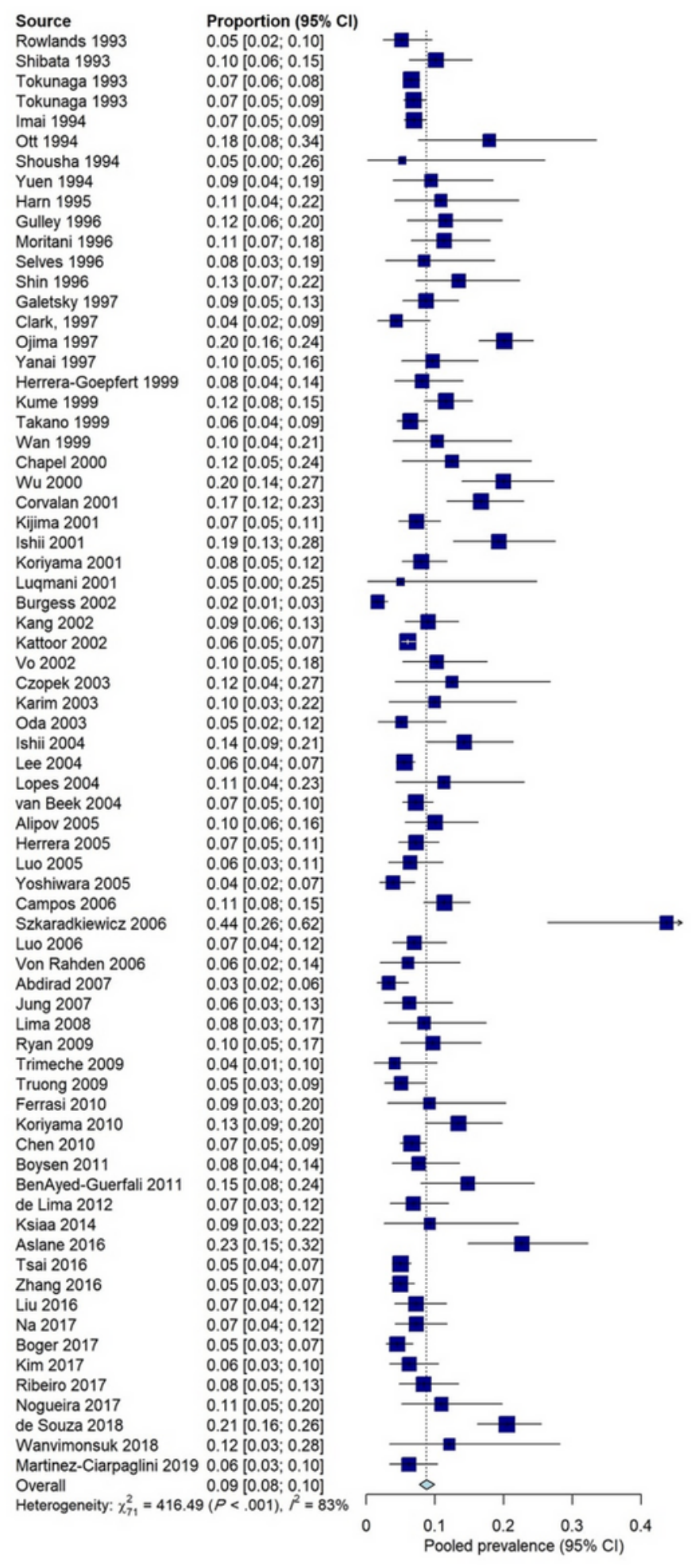

Figure 2

Forest plot of the prevalence of EBV infection among gastric cancer patients, according to the random effect model 


\begin{tabular}{|c|c|}
\hline & Proportion (95\% \\
\hline Shibata 1993 & $0.06[0.02 ; 0.13]$ \\
\hline Tokunaga 1993 & $0.03[0.02 ; 0.05]$ \\
\hline Tokunaga 1993 & $0.03[0.01 ; 0.05]$ \\
\hline Shousha 1994 & $0.20[0.01 ; 0.72]$ \\
\hline Yuen 1994 & $0.00[0.00 ; 0.15]$ \\
\hline Harn 1995 & $0.07[0.01 ; 0.24]$ \\
\hline Gulley 1996 & $0.06[0.01 ; 0.19]$ \\
\hline Selves 1996 & $0.06[0.00 ; 0.30]$ \\
\hline Shin 1996 & $0.10[0.02 ; 0.27]$ \\
\hline Galetsky 1997 & $0.02[0.00 ; 0.08]$ \\
\hline Clark, 1997 & $0.02[0.00 ; 0.10]$ \\
\hline Yanai 1997 & $0.09[0.02 ; 0.24]$ \\
\hline ra 1999 & $0.07[0.02 ; 0.17]$ \\
\hline 1999 & $0.03[0.01 ; 0.08]$ \\
\hline Wu 2 & $0.20[\mathrm{C}$ \\
\hline 2001 & 0.12 [C \\
\hline 01 & \\
\hline & \\
\hline 2001 & 0.06 \\
\hline 003 & 0.10 \\
\hline 03 & 0.06 \\
\hline & 0.06 \\
\hline & 0.01 \\
\hline Alip & 0.04 \\
\hline 005 & 0.07 \\
\hline ra 2005 & 0.04[ \\
\hline 2006 & 0.06[ \\
\hline Luo 2 & 0.00[ \\
\hline 2007 & 0.01[ \\
\hline Jung & $0.03[\mathrm{C}$ \\
\hline Lime & $0.00[\mathrm{C}$ \\
\hline he 2009 & $0.00[0$ \\
\hline 2009 & 0.01[ \\
\hline Che & 0.03[ \\
\hline & 0.18[ \\
\hline & $0.03[\mathrm{C}$ \\
\hline Ksia & $0.00[\mathrm{C}$ \\
\hline Aslar & 0.13[ \\
\hline & $0.02[\mathrm{C}$ \\
\hline Zhat & 0.02 \\
\hline Liu 2 & $0.09[0.0$ \\
\hline $\mathrm{Na} 2$ & $0.03[0.00 ; 0.12]$ \\
\hline Bog & $0.01[0.0$ \\
\hline Ribe & $1.00[0.9$ \\
\hline 2017 & $0.18[0.1$ \\
\hline & $0.18[0.11 ; 0.26]$ \\
\hline Martinez 2019 & $0.04[0.01 ; 0.12]$ \\
\hline Overall & $0.06[0.04 ; 0.08]$ \\
\hline \multicolumn{2}{|c|}{ Heterogeneity: $x_{s 6}^{2}=179.14(P<.001), f^{2}=74 \%$} \\
\hline
\end{tabular}

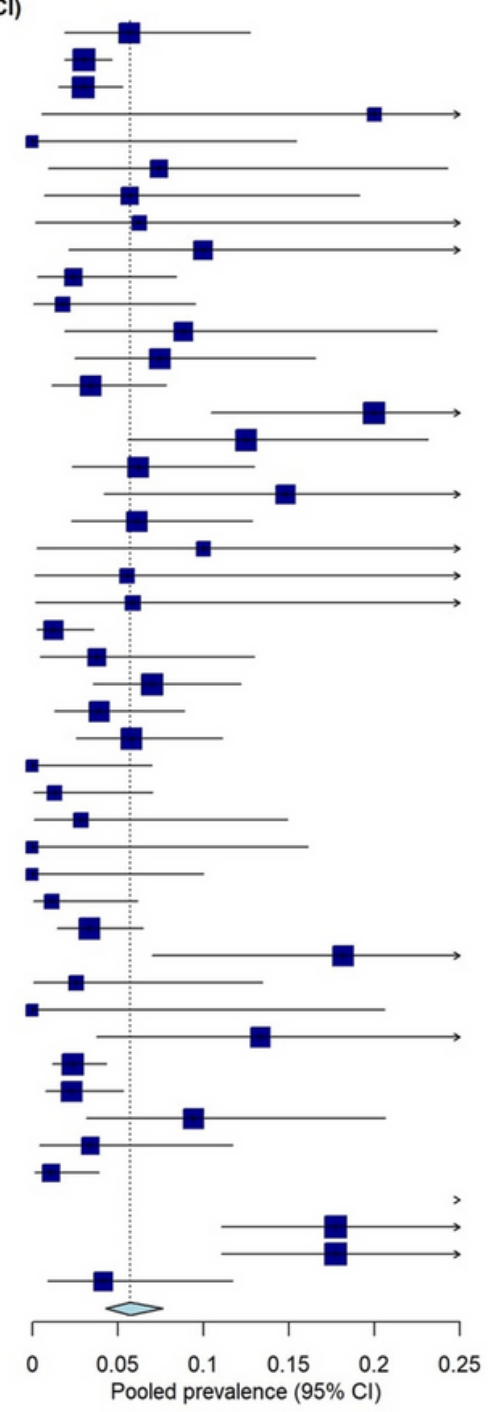

Figure 3A

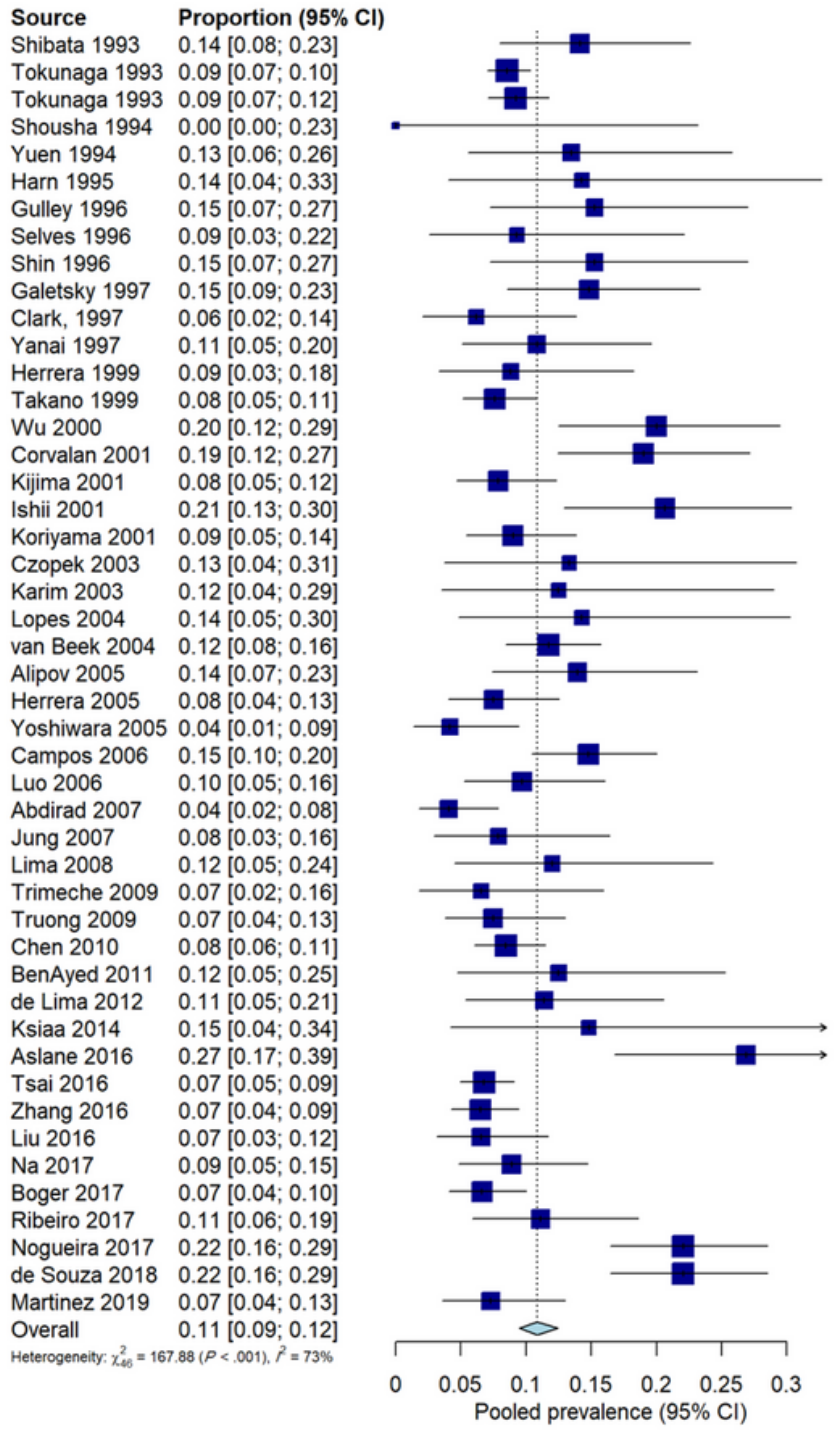

Figure $3 \mathrm{~B}$

\section{Figure 3}

Forest plot of the prevalence of EBV infection among gastric cancer patients, according to the random effect model in females (figure $3 \mathrm{~A}$ ) and males (figure 3B) 


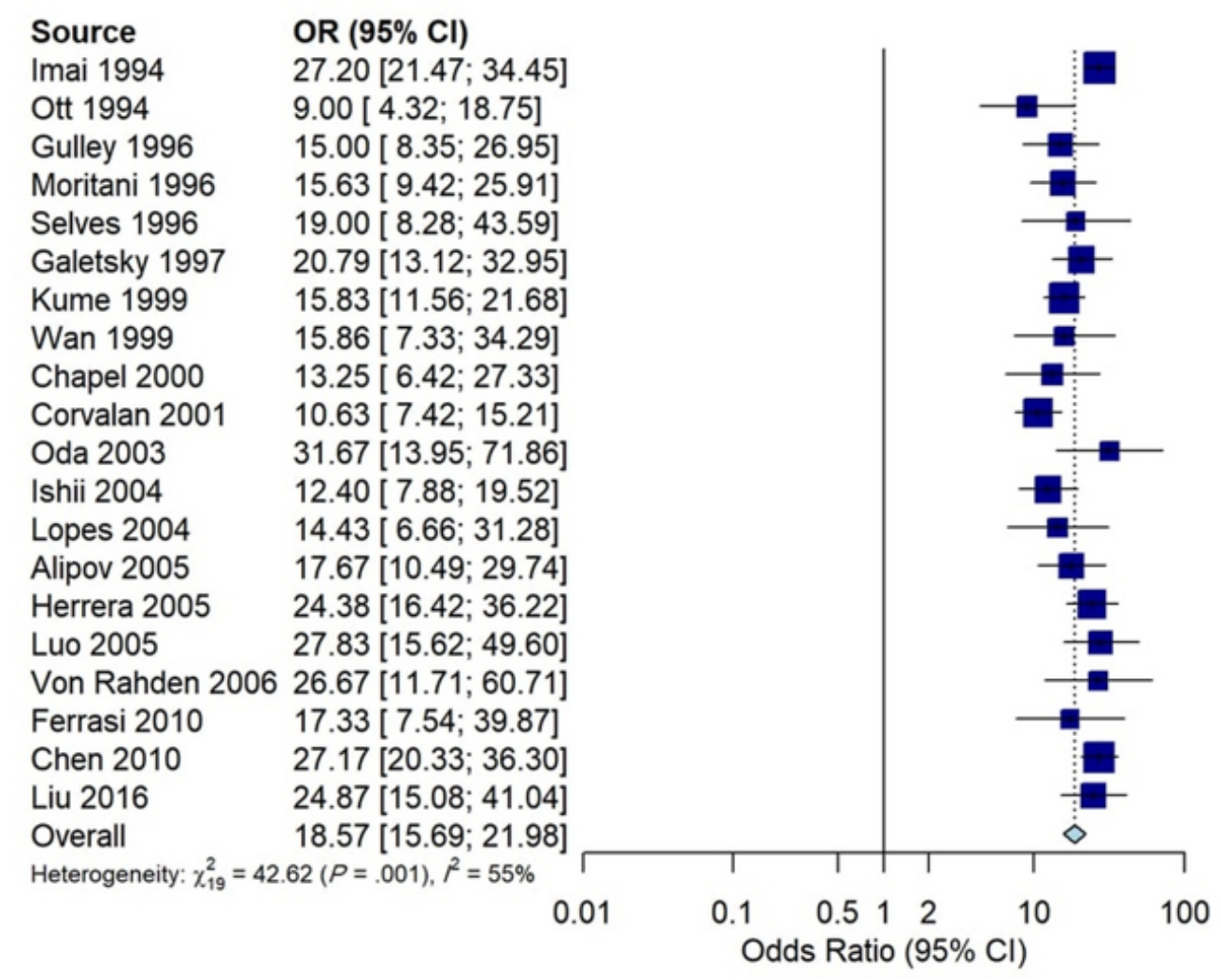

Figure 4A

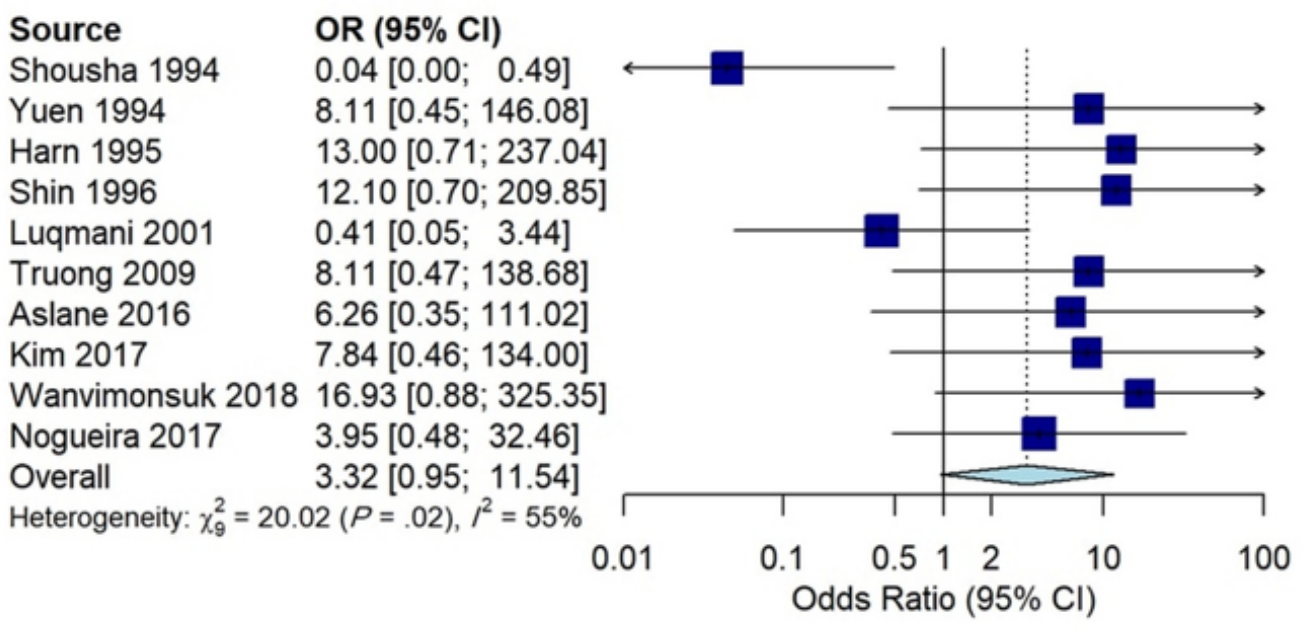

Figure 4B

\section{Figure 4}

Forest plot of the association between EBV infection and gastric cancer risk (according to random effect model) in studies with match pairs design (figure 4A) and non-match pairs design (figure 4B) 


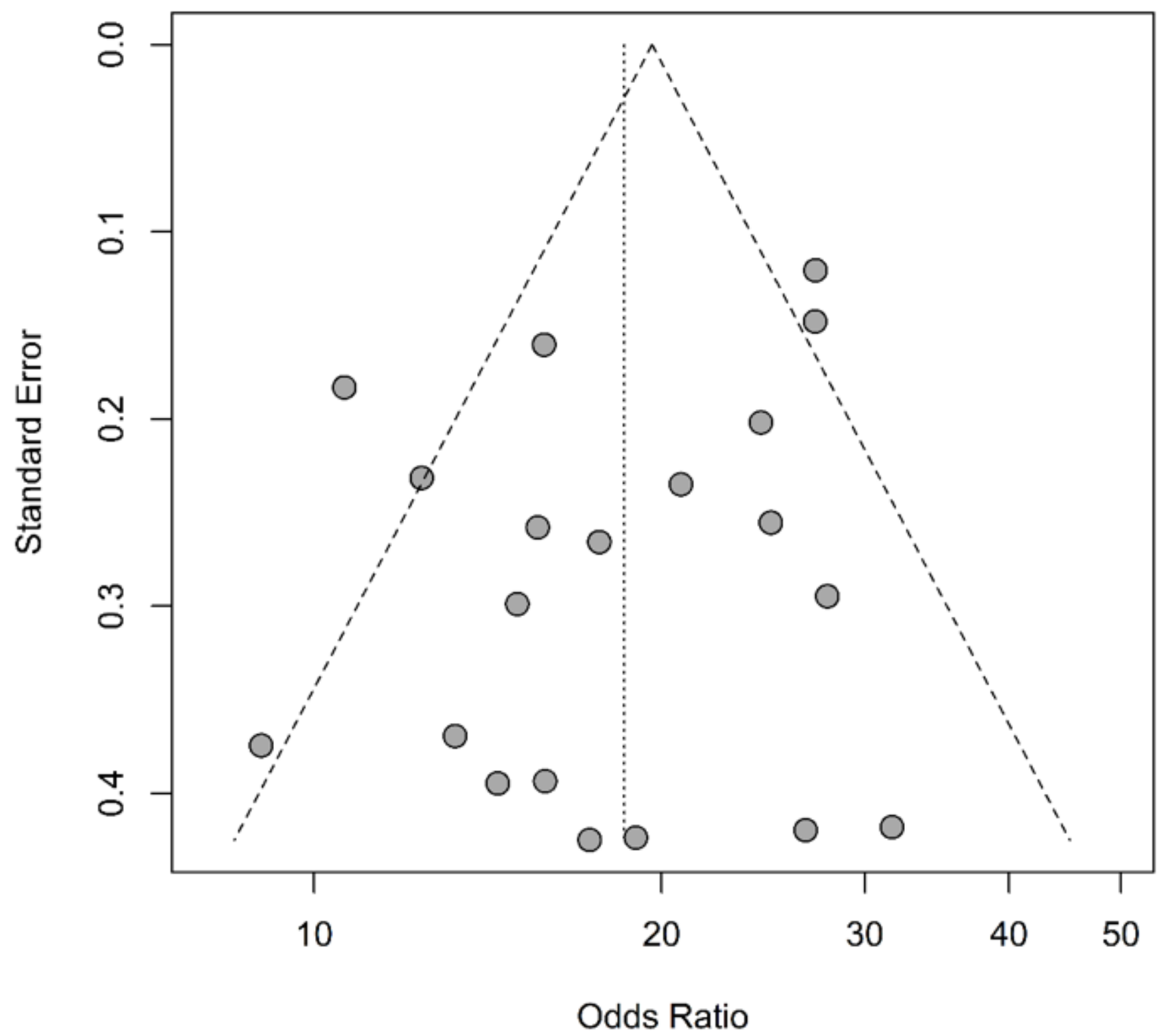

Figure 5

Funnel plot for assessment of publication bias.

\section{Supplementary Files}

This is a list of supplementary files associated with this preprint. Click to download.

- PRISMA2009checklist.doc

- Additionalfile1.docx 